\title{
Evaluation of acidifying nitrogen fertilizers in avocado trees with iron deficiency symptoms
}

\author{
Fernando Granja ${ }^{2}$, José Ignacio Covarrubias ${ }^{1 *}$ \\ ${ }^{1}$ Facultad de Ciencias Agronómicas, Universidad de Chile, Av. Santa Rosa 11315, Santiago, Chile. ${ }^{2}$ Facultad \\ Agropecuaria y de Recursos Naturales Renovables, Universidad Nacional de Loja, Av. Pio Jaramillo Alvara- \\ do y Reinaldo Espinosa, La Argelia, Ecuador.*Corresponding author: jcovarru@uchile.cl
}

\begin{abstract}
:
The control of iron chlorosis by synthetic Fe chelates is costly, and their application can have adverse environmental impacts. We investigated the effectiveness of alternative strategies to prevent Fe chlorosis in avocado based on different acidifying nitrogen fertilizers. The experiment was conducted on a commercial orchard of avocado $c v$. Hass cultivated in a calcareous soil. The application of $\left(\mathrm{NH}_{4}\right)_{2} \mathrm{SO}_{4}$ was highly effective at reducing the soil $\mathrm{pH}$ and, when applied with a nitrification inhibitor, at increasing the leaf chlorophyll concentration in trees. Fertilization with urea was also effective at increasing leaf chlorophyll, but only when applied without a nitrification inhibitor. However, the acidifying effect of urea on the soil was significantly lower than $\left(\mathrm{NH}_{4}\right)_{2} \mathrm{SO}_{4}$. The different $\mathrm{N}$ sources also modified the concentration of $\mathrm{N}_{-} \mathrm{NO}_{3}{ }_{3}, \mathrm{~N}_{-} \mathrm{NH}_{4}^{+}$and total $\mathrm{N}$ within the leaves, but did not influence the length of the shoots or the leaf gaseous exchange. These results suggest that the fertilization strategy based on $\left(\mathrm{NH}_{4}\right)_{2} \mathrm{SO}_{4}+$ DMPP or urea can be an effective and sustainable alternative to counteract Fe chlorosis symptoms in avocado trees. Our results provide evidence of the effectiveness of agronomic strategies, alternative to synthetic Fe chelates, for preventing Fe deficiency in avocado.
\end{abstract}

Keywords: Ammonium sulfate, urea, DMPP, iron chlorosis, Persea americana Mill.

\section{Introduction}

Neutral to alkaline $\mathrm{pH}$ in the soils of many avocadogrowing areas results in frequent micronutrient deficiencies in avocado (Persea americana Mill.) orchards (Manthey and Crowley, 1997). Avocado trees grown under these conditions are frequently affected by more than one micronutrient scarcity, and in particular by iron $(\mathrm{Fe})$ deficiency. Some experiments into avocado cultivation in calcareous soils indicate that negative impacts may occur in fruit yield, tree growth, and disease resistance 
even in trees with mild symptoms of Fe chlorosis (Manthey and Crowley, 1997). Yet, despite exhaustive attempts to develop effective management techniques focused on supplementing avocado trees with metal micronutrient fertilizers, the $\mathrm{Fe}$ chlorosis persists in many cases. Iron is the fourth most abundant element in the earth's crust, however, its deficit in plants occurs because only a small fraction of $\mathrm{Fe}$ is available to plants (Rombolà and Tagliavini, 2006). This is mainly due to its low solubility in the rhizosphere in soils characterized by neutral to alkaline $\mathrm{pH}$ (Bityutskii et al., 2017). In this context, one of the main causes of $\mathrm{Fe}$ deficiency in fruit tree crops cultivated in such areas is the high calcium carbonate $\left(\mathrm{CaCO}_{3}\right)$ and bicarbonate $\left(\mathrm{HCO}_{3}^{-}\right)$concentrations in the soil due to the effect of such ions on the soil solution $\mathrm{pH}$ (Bityutskii et al., 2017; Rombolà and Tagliavini, 2006). In fact, higher $\mathrm{pH}$ favours carbonate or hydroxyl complexes (Rengel, 2015). In addition, high-pH soils range from calcareous (around $\mathrm{pH} 7$ ) to alkaline saline and sodic soils (pH 8 and higher), have major nutritional constraints (Fe and $\mathrm{P}$ deficiency) and/or toxicity of $\mathrm{Na}$ coupled with excess $\mathrm{HCO}_{3}^{-}$, water deficiency, mechanical impedance and poor aeration (Rengel, 2015).

Dicotyledonous plants, such as avocado, have evolved using Strategy I of Fe uptake, and consequently absorb $\mathrm{Fe}$ from the soil in its ferrous state. In soils with neutral to alkaline $\mathrm{pH}, \mathrm{Fe}$ is oxidized to the less soluble ferric state, and is consequently less available for root uptake (Kim and Guerinot, 2007). In such conditions, Strategy I plants, characterized by a high tolerance to $\mathrm{Fe}$ chlorosis, can react by lowering the $\mathrm{pH}$ of the rhizosphere through proton release catalyzed by ATP-ase enzyme activity and by the root exudation of some organic acids and phenolic compounds, which promotes the solubility/availability of $\mathrm{Fe}$ in the soil (Kim and Guerinot, 2007). Also, these plants can directly reduce $\mathrm{Fe}$ in roots by increasing the $\mathrm{Fe}^{3+}$-reductase (FCR) enzyme activity (Kim and Guerinot, 2007). However, Fe chlorosis susceptibility is highly variable among plant species and even among genotypes of the same species (Rombolà and Tagliavini, 2006). On the South American continent, among the most important fruit tree species, avocado is one of the most susceptible to Fe deficiency, since Fe chlorosis in avocado begins to manifest from soil pH levels above 7.0 (Manthey and Crowley, 1997). In avocado orchards cultivated in calcareous soils, growers usually try to solve such nutritional deficiencies by acidifying the soil with the application of sulfuric acid via the irrigation system. However, this management technique is hazardous for the agricultural operator and repeated applications may have deleterious effects on the soil microflora. Another widely used strategy that is very effective at controlling Fe deficiency is the use of Fe synthetic chelates. The cost of such strategy, however, can reach $60 \%$ of the total allocated for fertilizers in these orchards (Rombolà and Tagliavini, 2006). In addition, treatments with $\mathrm{Fe}$ chelates require repeated applications, and due to their high stability and solubility in soils, the risks of leaching and groundwater contamination are often high (Rombolà and Tagliavini, 2006).

Such evidences strongly suggests the need to adopt management strategies to improve Fe nutrition in crops considering soil and plant variables integrally. In such a context, the application of fertilizers whose absorption and/or chemical reactions acidify the rhizosphere and/or the soil solution could constitute a valid and sustainable strategy for the $\mathrm{Fe}^{3+}$ reduction, enabling $\mathrm{Fe}$ root absorption by the crop. It is known that the application of ammoniacal and amide nitrogen $(\mathrm{N})$ fertilizers may induce soil solution acidification, the intensity 
of which is mainly regulated by the amount of fertilizer applied and the soil management (Guo et al., 2010, Tong and $\mathrm{Xu}, 2012)$. In agricultural soils, the ammonium $\left(\mathrm{NH}_{4}^{+}\right)$concentration is in the range of $20-200 \mu \mathrm{M}$, and is frequently the preferred $\mathrm{N}$ source for some species. However, $\mathrm{NH}_{4}^{+}$is rapidly converted to nitrate $\left(\mathrm{NO}_{3}^{-}\right)$through the nitrification process, which implies the ammonia $\left(\mathrm{NH}_{3}\right)$ oxidation to hydroxylamine $\left(\mathrm{NH}_{2} \mathrm{OH}\right)$ and then to nitrite $\left(\mathrm{NO}_{2}^{-}\right)$by edaphic Nitrosomona spp. bacteria (Zerulla et al., 2001). Subsequently, the $\mathrm{NO}_{2}^{-}$is oxidized to $\mathrm{NO}_{3}^{-}$, through the activity of Nitrobacter bacteria. The mineralization rate of $\mathrm{NH}_{4}^{+}$depends on soil environmental factors, mainly soil organic matter content, soil moisture and temperature, and chemical and physical factors, which determine the potential supply rate of mineralizable N (Ramírez et al., 2016). Owing to the rapid nitrification rates in most aerobic soils, nitrate $\left(\mathrm{NO}_{3}^{-}\right)$is the primary $\mathrm{N}$ source for plants. For each $\mathrm{NH}_{4}^{+}$molecule oxidized to $\mathrm{NO}_{2}^{-}$, two $\mathrm{H}^{+}$ are released into the medium, decreasing the soil solution $\mathrm{pH}$ and promoting $\mathrm{Fe}^{3+}$ reduction.

Conversely, the absorption of some ions through the plasma membrane of root cells can induce rhizosphere acidification, favoring Fe solubilization and uptake by plants. Studies on grapevine conducted under controlled conditions showed that the presence of $\mathrm{NH}_{4}^{+}$ion in the substrate can counteract the negative effects of $\mathrm{NO}_{3}{ }^{-}$on $\mathrm{Fe}$ uptake by the roots (Jiménez et al. 2007; Covarrubias et $a l ., 2014)$. Nitrate absorption is mediated by a twoproton co-transport, which can increase the $\mathrm{pH}$ in the rhizosphere, reducing Fe solubility (Nikolic and Römheld 2002). Consequently, the presence of $\mathrm{NO}_{3}{ }^{-}$in the soil contributes to inducing Fe chlorosis in plants cultivated in lime soils (Kosegarten et al., 2001), and such an effect has also been observed in avocado (Bar and Kafkafi, 1992). In contrast, the absorption of $\mathrm{NH}_{4}^{+}$by plants induces acidification in the rhizosphere due to the excretion of protons through the enzyme $\mathrm{H}^{+}$-ATPase, favoring the reduction of $\mathrm{Fe}^{3+}$. As a result, the presence of $\mathrm{NH}_{4}^{+}$ in the rhizosphere could be beneficial to improving Fe nutrition in plants (Covarrubias et al., 2014). In order to improve the effectiveness of the positive effects induced by $\mathrm{NH}_{4}^{+}$in $\mathrm{Fe}$ nutrition, it may be important to employ strategies focused on maintaining the $\mathrm{NH}_{4}^{+}$concentration in the soil at medium-to-low levels by slowing down the oxidation of $\mathrm{NH}_{4}^{+}$exerted by the activity of Nitrosoma bacteria (Zerulla et al., 2001). In such a context, the use of nitrification inhibitors applied to the soil may contribute to optimizing $\mathrm{N}$ and $\mathrm{Fe}$ nutrition simultaneously as well as to reducing $\mathrm{NO}_{3}^{-}$leaching. However, in a tropical fruit species such as avocado there is no scientific evidence in this regard. The most frequently used synthetic nitrification inhibitors are DCD (dicyandiamide), nitrapyrin (2-chloro-6(trichloromethyl)pyridine) and the highly specific DMPP (3,4-dimethylpyrazol phosphate), which can inhibit nitrification at concentrations of $0.5-1.0 \mathrm{~kg}$ active compound $\mathrm{ha}^{-1}$. In a controlled experiment conducted on wheat, the application of $\mathrm{NH}_{4}^{+}$with DMPP increased $\mathrm{Fe}$ concentration in grains (Selim and Mahmoud, 2015). Moreover, in a pot study conducted on grapevine cultivated in a calcareous soil, the application of $\mathrm{NH}_{4}^{+}+$DMPP increased leaf chlorophyll content and leaf stomata length compared to plants treated with $\mathrm{NO}_{3}^{-}$, suggesting that this treatment is effective for preventing $\mathrm{Fe}$ chlorosis in vineyards located in calcareous soils (Covarrubias et al., 2014). Such scientific evidence points to the potential of using $\mathrm{NH}_{4}^{+}$as $\mathrm{N}$ fertilizer to control Fe deficiency in crops. The present investigation endeavors to evaluate the effectiveness of ammoniacal fertilizers application in avocado trees with Fe deficiency symptoms. 


\section{Material and Methods}

\subsection{Plant material, experimental conditions and treatments}

The experiment was undertaken during the 20142015 season in a commercial orchard located in the Valparaiso Region, Chile $\left(32^{\circ} 48^{\prime} \mathrm{S}\right.$ and $\left.71^{\circ} 09^{\prime} \mathrm{W}\right)$ in an alluvial soil, classified as Aeric Calciaquolls (Gleyic Kastanozems) and belonging to Los Pidenes soil Series (CIREN, 1997). The trial was conducted on avocado (Persea americana Mill.) trees $c v$ Hass grafted on Mexicola rootstock. The trees were planted on October 2011 at the distance of $6 \mathrm{~m}$ between the rows and $3 \mathrm{~m}$ between trees along the row. In winter 2014, 36 avocado trees randomly located in the orchard, with evident and homogeneous Fe deficiency symptoms characterized by interveinal yellowing in young leaves (leaf chlorophyll concentration between 30 and $40 \mu \mathrm{g} \mathrm{cm}^{-2}$ ), were selected for the experiment. The treatments tested were: (i) trees fertilized with a $\mathrm{N}-\mathrm{NO}_{3}{ }_{3}^{-}$source applied to the soil (control: $\mathrm{Ca}\left(\mathrm{NO}_{3}\right)_{2}$ );

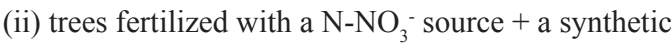
Fe chelate $\left(\mathrm{Ca}\left(\mathrm{NO}_{3}\right)_{2}+\mathrm{Fe}-\mathrm{EDDHA}\right)$; (iii) trees fertilized with urea as $\mathrm{N}-\mathrm{NH}_{4}^{+}$source applied to the soil (urea); (iv) trees fertilized with $\left(\mathrm{NH}_{4}\right)_{2} \mathrm{SO}_{4}$ as $\mathrm{N}-\mathrm{NH}_{4}^{+}$source applied to the soil $\left(\left(\mathrm{NH}_{4}\right)_{2} \mathrm{SO}_{4}\right) ;(\mathrm{v})$ trees fertilized with urea + a nitrification inhibitor applied to the soil (urea + DMPP); and (vi) trees fertilized with $\left(\left(\mathrm{NH}_{4}\right)_{2} \mathrm{SO}_{4}\right)+$ a nitrification inhibitor applied to the soil $\left(\left(\mathrm{NH}_{4}\right)_{2} \mathrm{SO}_{4}+\mathrm{DMPP}\right)$. Nitric nitrogen-fertilized trees received $1000 \mathrm{~mL}$ of $\mathrm{Ca}\left(\mathrm{NO}_{3}\right)_{2}$ solution $\left(10 \mathrm{~g} \mathrm{~N} \mathrm{~L}^{-1}\right)$ every 15 days from October 1 , 2014 to April 20, 2015, until the trees had received $140 \mathrm{~g} \mathrm{~N}$. The Fe chelate used was ethylenediamineN,N'-bis(2-hydroxyphenyl)acetic acid (Fe-EDDHA) (Basafer ${ }^{\circledR}$ PLUS, Compo $\left.{ }^{\circledR}\right) 5 \%$ ortho-ortho, and it was applied according to the soil plant analysis development (SPAD) index in leaves, in order to maintain an intensive green color of leaves (SPAD index >45). Doses of $500 \mathrm{~mL}$ of $6 \%$ Fe-EDDHA solution (4 g Fe-EDDHA L-1) were occasionally applied to the trees. During the season, Fe fertilized trees received $26 \mathrm{~g}$ Fe-EDDHA (1.56 g Fe per tree). The same amount of $\mathrm{N}$ supplied in the trees treated with $\mathrm{Ca}\left(\mathrm{NO}_{3}\right)_{2}$ was also applied in trees treated with urea or $\left(\mathrm{NH}_{4}\right)_{2} \mathrm{SO}_{4}$, through the application of 1000 $\mathrm{mL}$ solutions $\left(10 \mathrm{~g} \mathrm{~N} \mathrm{~L}^{-1}\right)$ every 15 days. In treatments $\mathrm{v}$ and $\mathrm{vi}$, the nitrification inhibition was maintained during the experiment with DMPP at doses of $1 \%$ of the $\mathrm{N}$ amount supplied. The orchard was regularly watered during the season with a drip irrigation system to recover the daily evapotranspiration rate. Weeds were frequently removed, and pest and disease protection was regularly carried out. The experimental design was completely randomized blocks, and each treatment was applied to six plants.

\subsection{Soil chemical properties}

In October 2014, before the treatments began, a soil sample composed by 15 sub-samples was collected from the avocado orchard at $40 \mathrm{~cm}$ depth (root zone), and some fertility parameters were determined. During the experiment, soil $\mathrm{pH}$ measurements were carried out in samples collected near the dripping bulb of each plant (at 30-40 cm depth). Chilean standard methods for soil analysis (Sadzawka et al., 2006) were used for soil $\mathrm{pH}_{\text {water }}(1: 2.5)$, determined using a portable $\mathrm{pH}$ meter (Elmetron model CP-4001). Samples were collected in early (March) and mid (May) autumn 2015, at 165 and 225 days of treatment, respectively.

\subsection{Leaf chlorophyll concentration and plant growth}

Leaf chlorophyll concentration was measured during the season in four shoots per tree every 30 days on 
four points of the first completely expanded leaf with a Minolta SPAD 502 portable greenness meter (Konica Minolta, Inc., Osaka, Japan). The SPAD value was previously calibrated with leaf chlorophyll concentration $\left(\mathrm{R}^{2}=0.97, \mathrm{p}<0.0001\right)$ in 16 leaves with different degrees of chlorosis according to Wellburn's method (1994). On each leaf, 2 discs of $12 \mathrm{~mm}^{2}$ diameter were ground with a pestle, and submitted to an extraction solution with cold acetone $80 \% \mathrm{v} / \mathrm{v}$. The resulted extracts were vortexed and centrifuged at $4000 \mathrm{~g}$ for $10 \mathrm{~min}$ at $4{ }^{\circ} \mathrm{C}$, and the supernatants were collected and submitted to a new extraction and centrifugation. The supernatants were used measure the absorbance at 663 and $646 \mathrm{~nm}$ using a spectrophotometer (Jasco V-630, Tokyo, Japan). During the season, the length of the same shoots selected for the chlorophyll determinations was determined every 30 days.

\subsection{Leaf gas exchange}

Leaf gas exchange was measured on each tree using an infrared gas analyzer (IRGA, LCi-ADC, London, United Kingdom). During the experiment, measurements were performed on the first mature leaf inserted in shoots of the middle third of the tree. Net photosynthesis was measured when foliar $\mathrm{CO}_{2}$ uptake was steady. Gas-exchange measurements including net photosynthesis ( $\mu \mathrm{mol} \quad \mathrm{CO}_{2} \mathrm{~m}^{-2} \mathrm{~s}^{-1}$ ), stomatal conductance $\left(\mathrm{mmol} \quad \mathrm{CO}_{2} \mathrm{~m}^{-2} \mathrm{~s}^{-1}\right)$ and transpiration $\left(\mu \mathrm{mol} \mathrm{H} \mathrm{H} \mathrm{m}^{-2} \mathrm{~s}^{-1}\right)$ were taken at 12:00 pm and 4:00 pm on January 12, 2015 (72 days after treatment imposition). During the measurement performed at 12:00 pm, the photosynthetically active radiation (PAR) and the environmental temperature were around 1700-1800 $\mu \mathrm{mol}$ photons $\mathrm{m}^{-2} \mathrm{~s}^{-1}$ and $28{ }^{\circ} \mathrm{C}$ respectively, whereas at 4:00 pm, the PAR was around $1200-1300 \mu \mathrm{mol}$ photons $\mathrm{m}^{-2} \mathrm{~s}^{-1}$ and the temperature was $32{ }^{\circ} \mathrm{C}$.

\subsection{Leaf $\mathrm{N}-\mathrm{NO}_{3}{ }_{3}^{-}, \mathrm{N}-\mathrm{NH}_{4}^{+}$and total $\mathrm{N}$ concentrations}

In April 2015, at 155 days of treatment, samples of 20 healthy and fully expanded leaves were collected from each tree and analyzed for $\mathrm{N}^{-} \mathrm{NO}_{3}{ }^{-}, \mathrm{N}_{-} \mathrm{NH}_{4}^{+}$and total $\mathrm{N}$ concentrations. The samples were oven-dried at $75^{\circ} \mathrm{C}$ and ground to pass a 40-mesh screen. The leaf $\mathrm{N}^{-\mathrm{NO}_{3}}{ }^{-}$ concentration was determined by the extraction with an aluminum sulfate $\left(\mathrm{Al}_{2}\left(\mathrm{SO}_{4}\right)_{3}\right)$ solution and subsequent determination by ion-selective electrode (ISE) (Miller, 1998). The leaf $\mathrm{N}-\mathrm{NH}_{4}{ }^{+}$concentration was determined colorimetrically using a wavelength of $650 \mathrm{~nm}$, according to Beathgen and Alley (1989). Total leaf $\mathrm{N}$ concentrations were determined by Kjeldahl method (Schuman et al., 1973).

\subsection{Statistics}

Comparison of means and analysis of variance between treatments were done using the Infostat software according to a completely random block design. If significant differences were found with F-tests, means were compared using the Tukey test $(\mathrm{P} \leq 0.05)$. Analyses were performed on raw data to maximize variance homogeneity.

\section{Results}

\subsection{Soil chemical properties}

The soil chemical properties determined in the composed soil sample collected before the trial establishment are described in the Table 1. The results obtained, show an initial soil $\mathrm{pH}$ value of 8.1 (Table 1). During the experiment, the soil pH showed significant differences between treatments (Figure 1). In the measurement taken at 165 days of treatment (March 2015), the results obtained indicate that the fertilization with $\left(\mathrm{NH}_{4}\right)_{2} \mathrm{SO}_{4}$, with or 
without DMPP, decreased the soil $\mathrm{pH}$ compared to the other treatments (Figure 1). After two months, at 225 days of treatment (May 2015), the effect of
$\left(\mathrm{NH}_{4}\right)_{2} \mathrm{SO}_{4}$ with or without DMPP kept the soil $\mathrm{pH}$ steady compared to the control and the other fertilization strategies assessed (Figure 1).

Table 1. Chemical properties of the soil utilized in the experiment.

\begin{tabular}{|c|c|c|}
\hline Fertility & Unit & Value \\
\hline $\mathrm{pH}$ (water, ratio $1: 2,5$ ) & $1: 2.5$ & 8.1 \\
\hline Electric conductivity (in extract) & $\mathrm{dS} / \mathrm{m}$ & 1.3 \\
\hline Organic matter & $\%$ & 4.4 \\
\hline Available nitrogen $(\mathrm{N})$ & $\mathrm{mg} / \mathrm{kg}$ & 51 \\
\hline Available phosphorus (P) & $\mathrm{mg} / \mathrm{kg}$ & 18 \\
\hline Available potassium (K) & $\mathrm{mg} / \mathrm{kg}$ & 97 \\
\hline \multicolumn{3}{|l|}{ Exchangeable cations } \\
\hline \multirow[t]{2}{*}{ Calcium $(\mathrm{Ca})$} & $\mathrm{cmol}+/ \mathrm{kg}$ & 17.4 \\
\hline & $\% \mathrm{CEC}$ & 80 \\
\hline \multirow[t]{2}{*}{ Magnesium (Mg) } & $\mathrm{cmol}+/ \mathrm{kg}$ & 3.5 \\
\hline & $\%$ CEC & 16 \\
\hline \multirow[t]{2}{*}{ Potassium (K) } & $\mathrm{cmol}+/ \mathrm{kg}$ & 0.25 \\
\hline & $\%$ CEC & 1.1 \\
\hline \multirow[t]{2}{*}{ Sodium (Na) } & $\mathrm{cmol}+/ \mathrm{kg}$ & 0.32 \\
\hline & $\%$ CEC & 1.5 \\
\hline CEC (Cation Exchange Capacity) & $\mathrm{cmol}+/ \mathrm{kg}$ & 21.7 \\
\hline \multicolumn{3}{|l|}{ Available microelements } \\
\hline$(\mathrm{Fe})$ & $\mathrm{mg} / \mathrm{kg}$ & 14.4 \\
\hline Manganese & $\mathrm{mg} / \mathrm{kg}$ & 19.0 \\
\hline Zinc & $\mathrm{mg} / \mathrm{kg}$ & 2.0 \\
\hline Copper & $\mathrm{mg} / \mathrm{kg}$ & 8.5 \\
\hline Boron & $\mathrm{mg} / \mathrm{kg}$ & 3.5 \\
\hline \multicolumn{3}{|l|}{ Carbonates } \\
\hline Total carbonates & & 4.3 \\
\hline Active lime & & 2.5 \\
\hline
\end{tabular}

*For available microelements and exchangeable cations determinations, DTPA and ammonium acetate were used as extractants, respectively (Sadzawka et al., 2006). 


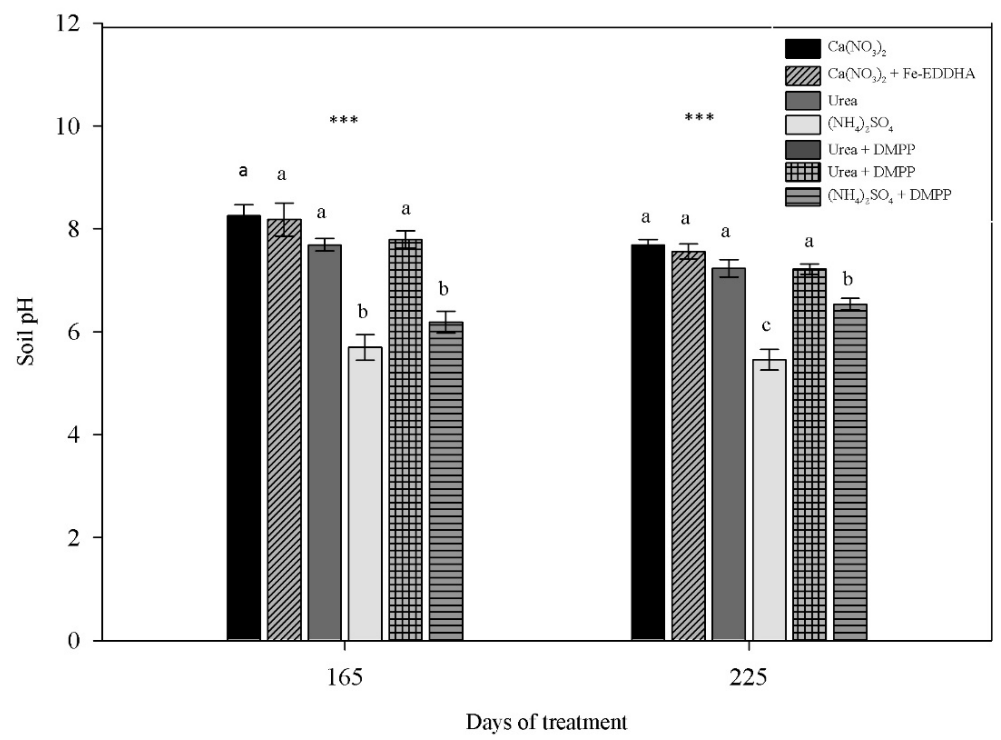

Figure 1. Soil $\mathrm{pH}$ for avocado trees $c v$ Hass treated with different nitrogen fonts to prevent Fe deficiency. Bars with the same letter in each date were not significantly different according to the DGC test. Data are mean $\pm \mathrm{SE}$ of six replicates. ***Significant at $\mathrm{P} \leq 0.001$ level. $\mathrm{Ca}\left(\mathrm{NO}_{3}\right)_{2}=$ calcium nitrate; EDDHA = ethylenediamine-N,N'bis(2-hydroxyphenyl)acetic acid; $\left(\mathrm{NH}_{4}\right) 2 \mathrm{SO}_{4}=$ ammonium sulphate; DMPP = 3,4-dimethylpyrazole phosphate (nitrification inhibitor).

\subsection{Leaf chlorophyll concentration and plant growth}

During the vegetative season, higher chlorophyll concentrations were recorded in the first expanded leaf from trees treated with $\mathrm{Ca}\left(\mathrm{NO}_{3}\right)_{2}+\mathrm{Fe}-\mathrm{EDDHA}$ and $\left(\mathrm{NH}_{4}\right)_{2} \mathrm{SO}_{4}+$ DMPP than trees supplied with $\left(\mathrm{NH}_{4}\right)_{2} \mathrm{SO}_{4}$, urea + DMPP and $\mathrm{Ca}\left(\mathrm{NO}_{3}\right)_{2}$ (Figure 2). Trees treated with urea showed a low leaf chlorophyll concentration from 60 to 120 days after treatments, and the chlorophyll level gradually increased until values similar to $\mathrm{Ca}\left(\mathrm{NO}_{3}\right)_{2}+\mathrm{Fe}$ EDDHA and $\left(\mathrm{NH}_{4}\right)_{2} \mathrm{SO}_{4}+$ DMPP treatments were reached (Figure 2). At the end of the season, data obtained revealed a significant shoot growth $(10-20 \mathrm{~cm})$ on the trees, however, no differences between treatments have been recorded in this parameter (Figure 3). 


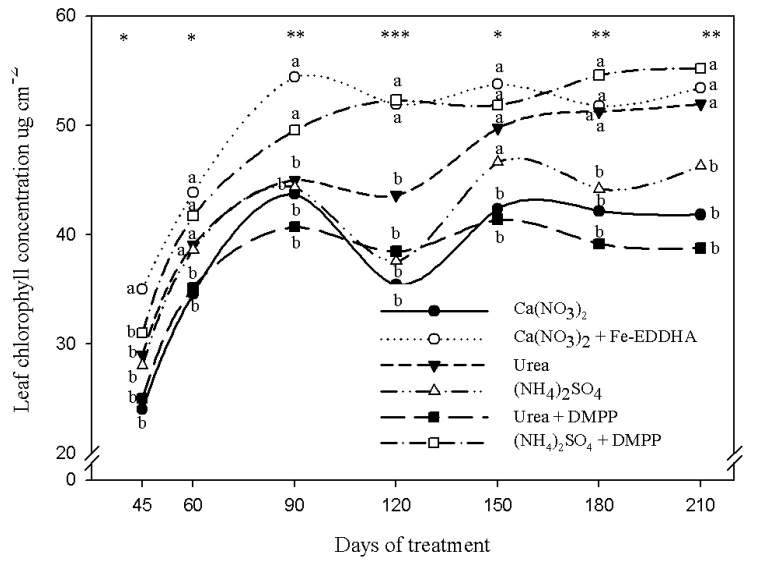

Figure 2. Leaf chlorophyll concentration in avocado trees $c v$ Hass treated with different nitrogen fonts to prevent Fe deficiency. Means with the same letter in each date were not significantly different according to the DGC test. Data are mean $\pm \mathrm{SE}$ of six replicates. *Significant at $\mathrm{P} \leq 0.05$ level; **Significant at $\mathrm{P} \leq 0.01$ level; ***Significant at $\mathrm{P} \leq 0.001$ level. $\mathrm{Ca}\left(\mathrm{NO}_{3}\right)_{2}=$ calcium nitrate; EDDHA = ethylenediamine-N,N'-bis(2-hydroxyphenyl)acetic acid; $\left(\mathrm{NH}_{4}\right) 2 \mathrm{SO}_{4}=$ ammonium sulphate; DMPP = 3,4-dimethylpyrazole phosphate (nitrification inhibitor).

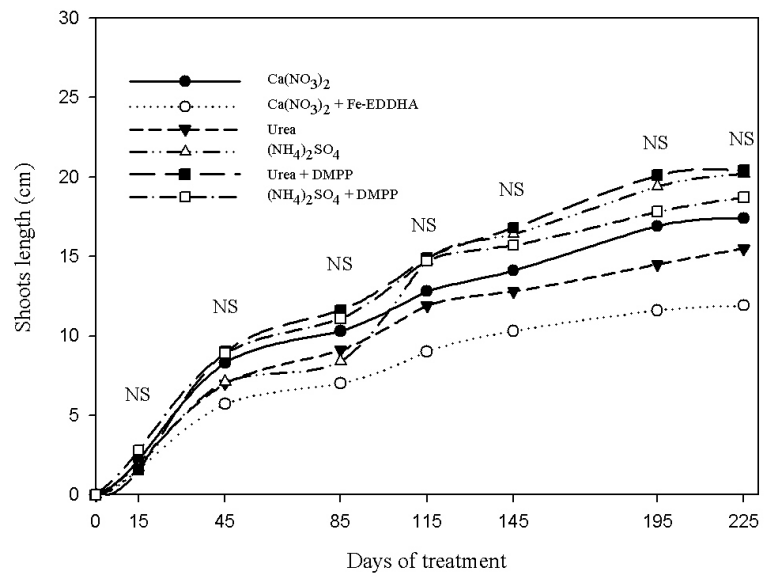

Figure 3. Shoots length $(\mathrm{cm})$ during the season in avocado trees $c v$ Hass treated with different nitrogen fonts to prevent Fe deficiency. Means with the same letter in each date were not significantly different according to the DGC test. Data are mean of six replicates. NS = not significant. $\mathrm{Ca}\left(\mathrm{NO}_{3}\right)_{2}=$ calcium nitrate; EDDHA = ethylenediamine-N,N'-bis(2-hydroxyphenyl)acetic acid; $\left(\mathrm{NH}_{4}\right) 2 \mathrm{SO}_{4}=$ ammonium sulphate; DMPP = 3,4-dimethylpyrazole phosphate (nitrification inhibitor). 


\subsection{Leaf gas exchange}

In the present work, the infrared gas analyzer registered a higher net photosynthesis, stomatal conductance and transpiration in leaves at 12:00 pm than values recorded at 16:00 pm (Table 2). No significant differences were detected, with the methodology used, in the leaf gaseous exchange parameters evaluated in our experiment (Table 2).

Table 2. Net photosinthesys $\left(\mathrm{A} ; \mu \mathrm{mol} \mathrm{m} \mathrm{m}^{-2} \mathrm{~s}^{-1}\right)$, stomatal conductance $\left(\mathrm{g}_{\mathrm{s}} ; \mathrm{mmol} \mathrm{m} \mathrm{m}^{-2} \mathrm{~s}^{-1}\right)$ and transpiration $(\mathrm{E}$; mmol m $\mathrm{m}^{-2} \mathrm{~s}^{-1}$ ) in leaves of avocado trees $c v$ Hass treated with different nitrogen fonts to prevent Fe deficiency. Measures were made 72 days after treatments, at 12:00 pm and 16:00 pm. $\mathrm{Ca}\left(\mathrm{NO}_{3}\right)_{2}=$ calcium nitrate; EDDHA $=$ ethylenediamine- $\mathrm{N}, \mathrm{N}$ '-bis(2-hydroxyphenyl)acetic acid; $\left(\mathrm{NH}_{4}\right) 2 \mathrm{SO}_{4}=$ ammonium sulphate; DMPP = 3,4-dimethylpyrazole phosphate (nitrification inhibitor).

\begin{tabular}{lcccccc}
\hline \multirow{2}{*}{ Treatments } & \multicolumn{2}{c}{$\mathrm{A}\left(\mu \mathrm{mol} \mathrm{m}^{-2} \mathrm{~s}^{-1}\right)$} & \multicolumn{2}{c}{$\mathrm{g}_{\mathrm{s}}\left(\mathrm{mmol} \mathrm{m}^{-2} \mathrm{~s}^{-1}\right)$} & \multicolumn{2}{c}{$\mathrm{E}\left(\mathrm{mmol} \mathrm{m}^{-2} \mathrm{~s}^{-1}\right)$} \\
\cline { 2 - 7 } & $12: 00$ & $16: 00$ & $12: 00$ & $16: 00$ & $12: 00$ & $16: 00$ \\
\hline $\mathrm{Ca}\left(\mathrm{NO}_{3}\right)_{2}$ & 11.4 & 8.8 & 0.14 & 0.10 & 4.6 & 2.9 \\
$\mathrm{Ca}\left(\mathrm{NO}_{3}\right)_{2}+\mathrm{Fe}-\mathrm{EDDHA}$ & 9.8 & 8.9 & 0.13 & 0.12 & 4.4 & 3.1 \\
$\mathrm{Urea}$ & 11.2 & 8.9 & 0.16 & 0.10 & 4.9 & 3.3 \\
$\left(\mathrm{NH}_{4}\right)_{2} \mathrm{SO}_{4}$ & 9.4 & 8.4 & 0.12 & 0.12 & 4.0 & 3.2 \\
$\mathrm{Urea}+\mathrm{DMPP}$ & 10.8 & 9.7 & 0.14 & 0.14 & 4.9 & 3.8 \\
$\left(\mathrm{NH}_{4}\right)_{2} \mathrm{SO}_{4}+\mathrm{DMPP}$ & 8.5 & 7.8 & 0.10 & 0.06 & 3.9 & 2.8 \\
Significance & $\mathrm{NS}$ & $\mathrm{NS}$ & $\mathrm{NS}$ & $\mathrm{NS}$ & $\mathrm{NS}$ & $\mathrm{NS}$ \\
\hline
\end{tabular}

Data are mean of six replicates. NS $=$ not significant.

3.4 Leaf $\mathrm{N}-\mathrm{NO}_{3}-, \mathrm{N}-\mathrm{NH}_{4}^{+}$and total $\mathrm{N}$ concentrations

The results concerning the leaf $\mathrm{N}$ concentration indicate that the different fertilization strategies influenced the $\mathrm{N}_{-} \mathrm{NO}_{3}$ - and $\mathrm{N}-\mathrm{NH}_{4}^{+}$content in leaves. In contrast, no statistical differences between treatments were registered in the leaf total $\mathrm{N}$ concentration (Table 3). The fertilization with $\left(\mathrm{NH}_{4}\right)_{2} \mathrm{SO}_{4}+$ DMPP significantly decreased the leaf $\mathrm{N}_{-} \mathrm{NO}_{3}$ - concentration compared to the other treatments (Table 4). On the other hand, the addition of $\mathrm{Ca}\left(\mathrm{NO}_{3}\right)_{2}$ increased the $\mathrm{N}-\mathrm{NH}_{4}{ }^{+}$concentration in leaves as compared with the other treatments (Table 3). 
Table 3. Concentration of $\mathrm{N}^{-\mathrm{NO}_{3}}{ }^{-}\left(\mathrm{mg} \mathrm{kg}^{-1}\right), \mathrm{N}^{-\mathrm{NH}_{4}}{ }^{+}\left(\mathrm{mg} \mathrm{kg}^{-1}\right)$ and $\mathrm{N}$-total (\%) in leaves of avocado trees $c v$ Hass treated with different nitrogen fonts to prevent Fe deficiency. $\mathrm{Ca}\left(\mathrm{NO}_{3}\right)_{2}=$ calcium nitrate; EDDHA = ethylenediamine-N,N'-bis(2-hydroxyphenyl)acetic acid; $\left(\mathrm{NH}_{4}\right) 2 \mathrm{SO}_{4}=$ ammonium sulphate; DMPP = 3,4-dimethylpyrazole phosphate (nitrification inhibitor).

\begin{tabular}{lccc}
\hline Treatments & $\begin{array}{c}\mathrm{N}^{-\mathrm{NO}_{3}}{ }^{-} \\
\left(\mathrm{mg} \mathrm{kg}^{-1}\right)\end{array}$ & $\begin{array}{c}\mathrm{N}^{-\mathrm{NH}_{4}}{ }^{+} \\
\left(\mathrm{mg} \mathrm{kg}^{-1}\right)\end{array}$ & $\begin{array}{c}\text { Total N } \\
(\%)\end{array}$ \\
\hline $\mathrm{Ca}\left(\mathrm{NO}_{3}\right)_{2}$ & $216.3 \mathrm{a}$ & $861 \mathrm{a}$ & 2.6 \\
$\mathrm{Ca}\left(\mathrm{NO}_{3}\right)_{2}+\mathrm{Fe}-\mathrm{EDDHA}$ & $239.5 \mathrm{a}$ & $552 \mathrm{~b}$ & 2.4 \\
$\mathrm{Urea}$ & $246.3 \mathrm{a}$ & $516 \mathrm{~b}$ & 2.4 \\
$\left(\mathrm{NH}_{4}\right)_{2} \mathrm{SO}_{4}$ & $217.3 \mathrm{a}$ & $585 \mathrm{~b}$ & 2.5 \\
Urea $+\mathrm{DMPP}$ & $212.1 \mathrm{a}$ & $622 \mathrm{~b}$ & 2.5 \\
$\left(\mathrm{NH}_{4}\right)_{2} \mathrm{SO}_{4}+\mathrm{DMPP}$ & $185.8 \mathrm{~b}$ & $626 \mathrm{~b}$ & 2.3 \\
Significance & $*$ & $* *$ & $\mathrm{NS}$ \\
\hline
\end{tabular}

Data are mean of six replicates. NS $=$ not significant; *Significant at $\mathrm{P} \leq 0.05$ level; **Significant at $\mathrm{P} \leq 0.01$ level.

\section{Discussion}

Data concerning the soil $\mathrm{pH}$ after treatment imposition indicate a strong soil acidification induced by the fertilization with $\left(\mathrm{NH}_{4}\right)_{2} \mathrm{SO}_{4}$, with or without DMPP, whereas the application of urea did not significantly modify this soil property. Soil $\mathrm{pH}$ has a dominant effect on solubility and therefore availability of ions, whereas low $\mathrm{pH}$ shifts the equilibrium toward free metal cations and protonated anions, higher $\mathrm{pH}$ favours carbonate or hydroxyl complexes (Rengel, 2015). Reductions in the soil $\mathrm{pH}$ as a consequence of $\left(\mathrm{NH}_{4}\right)_{2} \mathrm{SO}_{4}$ supply in calcareous soils have been previously reported (Chien et al., 2011), and have been attributed to the descaling action exerted by the reaction of the sulfate group $\left(\mathrm{SO}_{4}^{-2}\right)$ contained in the fertilizer with the calcium carbonate $\left(\mathrm{CaCO}_{3}\right)$ present in the soil to form calcium sulfate $\left(\mathrm{CaSO}_{4}\right)$. Calcium sulfate may be highly susceptible to being carried down deep into the soil by rainwater or irrigation (Chien et al., 2011). In calcareous soils, Ca is the most abundant cation and its loss promotes $\mathrm{H}^{+}$ fixation to counteract the complex charge, triggering medium acidification (Chien et al., 2011). In addition, the $\mathrm{NH}_{4}^{+}$ion present in the $\left(\mathrm{NH}_{4}\right)_{2} \mathrm{SO}_{4}$ molecule also contributes to decreasing the soil $\mathrm{pH}$, since the conversion of $1 \mathrm{~mol} \mathrm{NH}_{4}^{+}$ion to $\mathrm{NO}_{2}^{-}$(nitrification process) releases $2 \mathrm{~mol} \mathrm{H}^{+}$into the soil solution. Some authors suggest that the nitrification of $\mathrm{NH}_{4}^{+}$based fertilizers contributes more to soil acidification than acid deposition and other factors (Guo et al., 2010, Tong and $\mathrm{Xu}, 2012$ ), which could explain the lower acidifying capacity of $\left(\mathrm{NH}_{4}\right)_{2} \mathrm{SO}_{4}$ when applied with the nitrification inhibitor DMPP as recorded in our experiment. In contrast, the $\mathrm{pH}$ registered in the soil treated with urea was similar to that treated with $\mathrm{Ca}\left(\mathrm{NO}_{3}\right)_{2}$. Urea is an amide classified as an $\mathrm{N}_{-} \mathrm{NH}_{4}^{+}$ source, and therefore its hydrolysis and the subsequent oxidation of the $\mathrm{NH}_{4}^{+}$group should release protons, thus increasing the medium acidification (Chien et al., 2011). In acid soils, the addition of urea may accelerate nitrification and even soil acidification, 
since it increases the ammonia-oxidizing bacteria population (Tong and $\mathrm{Xu}, 2012$ ). However, some studies into different $\mathrm{N}$ sources applied in calcareous soils have reported significant $\mathrm{N}$ loss when supplied as urea, due to $\mathrm{NH}_{3}$ volatilization as a consequence of the high soil $\mathrm{pH}$ (Mahmood et al., 2011). Possibly, in our experiment, the $\mathrm{NH}_{3}$ volatilization phenomena occurred in the soil treated with urea, with or without DMPP, preventing a fraction of the urea-derived $\mathrm{NH}_{4}^{+}$ from being nitrified, and delaying soil acidification.

The leaf chlorophyll concentration in plants is often influenced by mineral nutrition and in particular by $\mathrm{N}$ and Fe status. Regarding Fe, different experimental experiences on Fe-deficient fruit tree species converge in that the interveinal yellowing in young leaves is the most common $\mathrm{Fe}$ deficiency symptom (Covarrubias et al., 2016). In fact, in several fruit tree species, the leaf chlorophyll concentration and Fe status of plants are significantly related (Rombolà and Tagliavini 2006). Taken together, this suggests that the leaf chlorophyll content is surely a reliable indicator of $\mathrm{Fe}$ nutrition in plants cultivated in calcareous soils. In this experiment, trees treated with Fe-EDDHA and $\left(\mathrm{NH}_{4}\right)_{2} \mathrm{SO}_{4}+$ DMPP showed a higher leaf chlorophyll concentration during the season, and from 120 days of treatment, the application of urea also increased this variable compared to plants treated with $\mathrm{Ca}\left(\mathrm{NO}_{3}\right)_{2}$. Beneficial effects of $\mathrm{NH}_{4}^{+}$on $\mathrm{Fe}$ (and other nutrients) availability and uptake that countered the adverse effects of $\mathrm{NO}_{3}^{-}$, have been reported by several authors, and may be due to the effect of a $\mathrm{N}$ source on the soil acidification that increases the concentration of the most available $\mathrm{Fe}^{+3}$ in the medium (Houdusse et al., 2007; Jiménez et al., 2007; Covarrubias et al., 2014). However, the application of $\left(\mathrm{NH}_{4}\right)_{2} \mathrm{SO}_{4}$ without DMPP was not effective at increasing leaf chlorophyll concentration in trees, despite it significantly reducing soil $\mathrm{pH}$, even more than ammonium $\left(\mathrm{NH}_{4}\right)_{2} \mathrm{SO}_{4}$ + DMPP. To explain such results, it is important to resort on the acidification mechanisms related to the presence of $\mathrm{NH}_{4}^{+}$in the soil. One of these is related to the $\mathrm{NH}_{4}^{+}$nitrification process, which acidifies the soil solution (previously explained). The other acidification mechanism occurs in the rhizosphere, since the $\mathrm{NH}_{4}{ }^{+}$absorption by root cells is mediated by an excretion of protons through the enzyme $\mathrm{H}^{+}$-ATPase. A fraction of the $\mathrm{NH}_{4}^{+}$supplied as $\left(\mathrm{NH}_{4}\right)_{2} \mathrm{SO}_{4}$ (without DMPP) was probably submitted to nitrification, acidifying the soil solution, but the $\mathrm{NO}_{3}$ - derived from such process has been absorbed by plant roots, inducing an alkalization in the rhizosphere. In contrast, it is highly likely that the DMPP supplied with $\left(\mathrm{NH}_{4}\right)_{2} \mathrm{SO}_{4}$ was effective at inhibiting $\mathrm{NH}_{4}^{+}$nitrification, reducing its acidification capacity in the soil solution, but increasing rhizosphere acidification through $\mathrm{NH}_{4}^{+}$ absorption by roots. Such evidence suggests that the addition of $\left(\mathrm{NH}_{4}\right)_{2} \mathrm{SO}_{4}$ with a nitrification inhibitor seems to be a more efficient strategy than the addition of $\left(\mathrm{NH}_{4}\right)_{2} \mathrm{SO}_{4}$ without a nitrification inhibitor to reduce the $\mathrm{Fe}^{3+}$ present in the rhizosphere, and therefore to improve the Fe nutrition in trees. Otherwise, it is possible that the $\mathrm{N}$ source, regardless of its effects on $\mathrm{Fe}$ nutrition, may influence the leaf chlorophyll concentration since $\mathrm{N}$ is a crucial element in different processes related to chlorophyll synthesis and concentration in leaves. In fact, some genes linked to chloroplast and chlorophyll biosynthesis activated by $\mathrm{N}$ have been previously reported in the literature (Scheible et al., 2004). In addition, some $\mathrm{NH}_{4}^{+}$advantages for plant $\mathrm{N}$ nutrition may also have contributed to the increase in leaf chlorophyll concentration such as the higher $\mathrm{N}$ uptake efficiency, since $\mathrm{NH}_{4}{ }^{+}$is more stable in the soil and less susceptible to leaching than $\mathrm{NO}_{3}^{-}$(Zheng-Qin et al., 2010). It is also well 
known that $\mathrm{NH}_{4}^{+}$requires less energy to be metabolized at cellular level than $\mathrm{NO}_{3}^{-}$(Loulakakis et al., 2009). In fact, $\mathrm{NH}_{4}^{+}$assimilation consumes from 2 to $5 \%$ of the total energy production, whereas $\mathrm{NO}_{3}^{-}$ assimilation consumes nearly 15\% (Loulakakis et al., 2009).

Our data showed that, from 150 days of treatment, the addition of urea increased the leaf chlorophyll concentration compared to the control trees. This result suggests that, despite the low effect of urea in reducing the soil $\mathrm{pH}$, possibly due to the $\mathrm{NH}_{3}$ volatilization, the trees probably managed to uptake a fraction of the $\mathrm{NH}_{4}^{+}$derived from it, promoting Fe absorption by roots. However, no effect was recorded on leaf chlorophyll concentration when urea was applied with DMPP. Apparently, in our experiment, the addition of DMPP substantially reduced the benefits of urea as $\mathrm{N}_{-} \mathrm{NH}_{4}^{+}$fertilizer to correct $\mathrm{Fe}$ chlorosis in avocados. In an experiment conducted by Liu et al. (2013), the application of urea with the nitrification inhibitors DMPP and DCD significantly increased the crop yield, plant biomass and nitrogen uptake in a wheat-maize cropping system due to a shift in the main soil inorganic $\mathrm{N}$ from $\mathrm{NO}_{3}^{-}$to $\mathrm{NH}_{4}^{+}$. However, in other investigation conducted on cotton, maize and wheat under greenhouse conditions using an alkaline calcareous soil, the addition of DCD significantly increased ${ }^{15} \mathrm{~N}$-labelled urea loss associated with a reduced fertilizer $\mathrm{N}$ uptake (Mahmood et al., 2011). Some authors have suggested that the increased fertilizer $\mathrm{N}$ loss, when urea is applied with a nitrification inhibitor, may be a result of a favored $\mathrm{NH}_{3}$ volatilization derived from the complete urea hydrolysis and blocking of nitrification (Nastri et al. 2000; Gioacchini et al. 2002). In fact, urea hydrolysis may increase the $\mathrm{pH}$ in the soil solution, and consequently, the balance of $\mathrm{NH}_{4}^{+}$ and $\mathrm{NH}_{3}$ could be displaced, thereby promoting the volatilization of $\mathrm{NH}_{3}$ in the atmosphere (Schlegel et al., 1986). Moreover, in addition to increasing fertilizer $\mathrm{N}$ loss, the nitrification inhibitor DCD is known to increase the soil-derived $\mathrm{N}$ loss (Gioacchini et al. 2002). These results suggest that the use of urea with a nitrification inhibitor in avocado trees established in alkaline calcareous soils probably increases $\mathrm{N}$ losses compared to urea applied without the nitrification inhibitor, thus counteracting the possible benefits obtained from inhibiting nitrification.

Contrary to our expectations, the effect of treatments on the leaf chlorophyll concentration was not associated with the shoot length and leaf gaseous exchange of avocados, the data for which showed a high variability within and among treatments. In grapevine, some authors have reported the occurrence of leaf chlorosis strongly associated with a shoot growth reduction in $\mathrm{Fe}$ deficient plants (Covarrubias et al., 2016,), whereas others did not observe any changes in shoot growth as a symptom of Fe-deficiency (Covarrubias et al., 2016). In an experiment conducted in hydroponic conditions, the grapevine genotype tolerant to $\mathrm{Fe}$ chlorosis 110 Richter reacted to Fe deficiency by reducing the main shoot length and biomass, without modifying the net photosynthesis or the leaf chlorophyll concentration, whereas opposite results were recorded in the susceptible genotype 3309-C (Covarrubias et al., 2016). The plant reaction to $\mathrm{Fe}$ deficiency linked to shoot growth and photosynthetic activity is likely related to the Fe chlorosis tolerance level, which is highly variable according to the species or genotype. Avocado is classified as a highly susceptible species to $\mathrm{Fe}$ deficiency, so it is probably not capable of counteracting the $\mathrm{Fe}$ deficit through physiological strategies based on shoot growth contraction, as do other $\mathrm{Fe}$ deficiency-tolerant 
species. It is also possible that the Fe deficiency severity of the trees treated with $\mathrm{NO}_{3}^{-}$was not so high as to modify the vegetative and physiological variables evaluated in the present experiment. Regarding photosynthetic activity, although a lower leaf chlorophyll concentration was recorded in trees treated with $\mathrm{Ca}\left(\mathrm{NO}_{3}\right)_{2},\left(\mathrm{NH}_{4}\right)_{2} \mathrm{SO}_{4}$ and urea + DMPP, it is possible that no changes occurred in the chlorophyll molecule composition, in the lipid peroxidation or in the thylakoid organization (Bertrand and Poirier, 2005). Thus, the trees treated with $\mathrm{Ca}\left(\mathrm{NO}_{3}\right)_{2},\left(\mathrm{NH}_{4}\right)_{2} \mathrm{SO}_{4}$ and urea + DMPP performed a similar photosynthetic activity in comparison with those treated with $\mathrm{Ca}\left(\mathrm{NO}_{3}\right)_{2}$ + Fe-EDDHA, urea and $\left(\mathrm{NH}_{4}\right)_{2} \mathrm{SO}_{4}+$ DMPP. Moreover, it should be mentioned that while it is known that Fe deficiency alters both chloroplast structure and photosynthesis rate in plants, the knowledge regarding the impact of Fe homeostasis on photosynthesis efficiency and therefore on biomass production is still limited in a tropical species as Persea americana Mill.

Data concerning the nutritional status of trees reveal that the use of $\left(\mathrm{NH}_{4}\right)_{2} \mathrm{SO}_{4}+$ DMPP reduced the leaf $\mathrm{N}-\mathrm{NO}_{3}{ }_{3}^{-}$concentration in avocados, indicating a lower $\mathrm{N}-\mathrm{NO}_{3}{ }^{-}$absorption in these trees compared to those subjected to the other treatments. Surprisingly, the application of the other $\mathrm{N}^{-\mathrm{NH}_{4}}{ }_{4}$ sources assessed did not reduce the leaf $\mathrm{NO}_{3}^{-}$concentration, which could be related to the different processes that each $\mathrm{N}_{-} \mathrm{NH}_{4}^{+}$ source suffered in the soil (nitrification in the case of $\left(\mathrm{NH}_{4}\right)_{2} \mathrm{SO}_{4}$ and volatilization in the case of urea). These results suggest that fertilization with $\left(\mathrm{NH}_{4}\right)_{2} \mathrm{SO}_{4}$ + DMPP is the most effective strategy for conserving $\mathrm{NH}_{4}^{+}$in soil, in which case the trees probably prefer this $\mathrm{N}$ source at the expense of $\mathrm{NO}_{3}^{-}$. Conversely, the application of $\mathrm{Ca}\left(\mathrm{NO}_{3}\right)_{2}$ increased the $\mathrm{N}^{-\mathrm{NH}_{4}}{ }^{+}$ accumulation, suggesting a possible retarding effect on the activity of key enzymes (GS/GOGAT) linked to the conversion of $\mathrm{NH}_{4}^{+}$to amino acids (Loulakakis et al., 2009). On the other hand, since the leaf total $\mathrm{Fe}$ concentration is not a reliable indicator of the $\mathrm{Fe}$ status in plants grown in calcareous soils because the total $\mathrm{Fe}$ concentration in chlorotic leaves are often similar or even greater than in green leaves ("chlorosis paradox" phenomena) (Römheld, 2000; Kosegarten et al., 2001), the concentration of this mineral in leaves was not considered in our investigation.

\section{Conclusions}

Data obtained indicate that the application of $\left(\mathrm{NH}_{4}\right)_{2} \mathrm{SO}_{4}$ is highly effective at reducing soil $\mathrm{pH}$, and, when applied with a nitrification inhibitor, at increasing the leaf chlorophyll concentration in trees. Additionally, fertilization with urea is also effective at increasing leaf chlorophyll, but only when applied without a nitrification inhibitor. However, the acidifying effect of urea in the soil is significantly lower than $\left(\mathrm{NH}_{4}\right)_{2} \mathrm{SO}_{4}$. In this experiment, the different $\mathrm{N}$

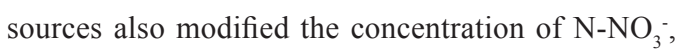
$\mathrm{N}-\mathrm{NH}_{4}^{+}$and total $\mathrm{N}$ within the leaves of avocados, but did not influence the shoot length or leaf gaseous exchange. These results suggest that the fertilization strategy based on $\left(\mathrm{NH}_{4}\right)_{2} \mathrm{SO}_{4}+$ DMPP or urea can be an effective and sustainable alternative to counteract Fe chlorosis symptoms in avocado trees, with a similar effectiveness to that achieved with Fe-EDDHA.

\section{Acknowledgements}

The authors wish to thank the Comisión Nacional de Investigación Científica y Tecnológica (CONICYT) of Chile for funding (FONDECYT project 11130328). 


\section{References}

Bityutskii, N., Yakkonen, K., Petrova, A., Nadporozhskaya, M. 2017. Xylem sap mineral analyses as a rapid method for estimation plantavailability of $\mathrm{Fe}, \mathrm{Zn}$ and $\mathrm{Mn}$ in carbonate soils: a case study in cucumber. J. Soil. Sci. Plant Nut. 17, 279-290.

Bar, Y., Kafkafi, U. 1992. Nitrate-induced irondeficiency chlorosis in avocado (Persea americana Mill.) rootstocks and its prevention by chloride. J. Plant Nutr. 15(10), 1739-1746.

Bertrand, M., Poirier, I. 2005. Photosynthetic organisms and excess of metals. Photosynthetica. 43(3), 345-353.

Baethgen, W.E., Alley, M.M. 1989. A manual colorimetric procedure for measuring ammonium nitrogen in soil and plant kjeldahl digests. Commun. Soil Sci. Plan. 20(9410), 961-969.

CIREN. 1997. Estudio Agrológico, V Región. Descripción de suelos, materiales y símbolos. Centro de Información de Recursos Naturales, Chile, Publicación 116, 371 p.

Chien, S.H., Gearhart, M.M., Villagarcía, S. 2011. Comparison of ammonium sulfate with other nitrogen and sulfur fertilizers in increasing crop production and minimizing environmental impact: a review. Soil Sci. 176(7), 327-335.

Covarrubias, J.I., Pisi, A., Rombolà, A.D. 2014. Evaluation of sustainable management techniques for preventing iron chlorosis in the grapevine. Aust J Grape Wine R. 20(1), 149-159.

Covarrubias, J.I., Retamales, C., Donnini, S., Rombolà, D.A., Pastenes, C. 2016. Contrasting physiological responses to iron deficiency in Cabernet Sauvignon grapevines grafted on two rootstocks. Sci. Hortic. 199, 1-8.
Gioacchini, P., Nastri, A., Marzadori, C., Giovannini, C. 2002. Influence of urease and nitrification inhibitors on $\mathrm{N}$ losses from soil fertilized with urea. Biol. Fertil. Soils. 36, 129-135.

Guo, J.H., Liu, X.J., Zhang, Y., Shen, J.L., Han, W.X., Zhang, W.F., Christie, P., Goulding, K.W.T., Vitousek, P.M., Zhang, F.S. 2010. Significant acidification in major Chinese croplands. Science. 327(5968), 1008-1010.

Houdusse, F. Garnica, M., García-Mina, J.M. 2007. Nitrogen fertilizer source effects on the growth and mineral nutrition of pepper (Capsicum annuum L.) and wheat (Triticum aestivum L.). J. Sci. Food Agr. 87, 2099-2105.

Jiménez, S., Gogorcena, Y., Hévin, C., Rombolà, A.D., Ollat, N. 2007. Nitrogen nutrition influences some biochemical responses to iron deficiency in tolerant and sensitive genotypes of Vitis. Plant Soil. 290, 343-355

Kim, S.A., Guerinot, M.L. 2007. Mining iron: Iron uptake and transport in plants. FEBS Lett. 581, 2273-2280.

Kosegarten, H., Hoffmann, B., Mengel, K. 2001. The paramount influence of nitrate in increasing apopastic $\mathrm{pH}$ of young sunflower leaves to induce Fe deficiency chlorosis, and the re-greening effect brought about by acidic foliar sprays. J. Plant Nutr. Soil Sci. 164, 155-163.

Liu, C., Wang, K., Zheng, X. 2013. Effects of nitrification inhibitors (DCD and DMPP) on nitrous oxide emission, crop yield and nitrogen uptake in a wheat-maize cropping system. Biogeosciences. 10, 2427-2437.

Loulakakis, K.A., Morot-Gaudry, J.F., Velanis, C.N., Skopelitis, D.S., Moschou, P.N., Hirel, B., Roubelakis-Angelakis, K.A. 2009. Advancements in nitrogen metabolism in grapevine. In: K.A. Roubelakis-Angelakis (Ed.). Grapevine 
Molecular Physiology \& Biotechnology. Second Edition. Springer Dordrecht Heidelberg, London, pp. 161-205.

Mahmood, T., Rehmat, A., Zahid, L., Wajid, I. 2011. Dicyandiamide increases the fertilizer $\mathrm{N}$ loss from an alkaline calcareous soil treated with ${ }^{15} \mathrm{~N}$-labelled urea under warm climate and under different crops. Biol. Fertil. Soils. 47, 619-631.

Manthey, J.A., Crowley, D.E. 1997. Leaf and root responses to iron deficiency in avocado. Jour. Plant Nutr. 20(6), 683-693.

Miller, O. 1998. Extractable nitrate in plant tissue: ion-selective electrode method. In: Y.P. Kalra (Eds.). Handbook of Methods for Plant Analysis. Soil and Plant Analysis Council, Inc. CRC Press, New York, 85-88 pp.

Nastri, A., Toderi, G., Bemati, E., Govi, G. 2000. Ammonia volatilization and yield response from urea applied to wheat with urease (NBPT) and nitrification (DCD) inhibitors. Agrochimica. 44, 231-239.

Nikolic, M., Römheld, V. 2002. Does high bicarbonate supply to roots change availability of iron in the leaf apoplast? Plant Soil. 241, 67-74.

Ramírez, M.V., Rubilar, R.A., Montes, C., Stape, J.L., Fox, T.R., Lee Allen, H. 2016. Nitrogen availability and mineralization in Pinus radiate stands fertilized mid-rotation at three contrasting sites. J Soil Sci Plant Nut. 16, 118-136.

Rengel, Z. 2015. Availability of Mn, Zn and Fe in the rhizosphere. J. Soil Sci. Plant Nut. 15, 397-409.

Rombolà, A.D., Tagliavini, M. 2006. Iron nutrition of fruit tree crops. In: L. Barton and J. Abadía (Eds.). Iron nutrition in plants and rhizospheric microorganisms. Springer Dordrecht, Netherlands, pp. 61-83.
Römheld, V. 2000. The chlorosis paradox: Fe inactivation as a secondary event in chlorotic leaves of grapevine. Jour. Plant Nutr. 23(11\&12), 1629-1643.

Sadzawka, A., Carrasco, M.A., Grez, R., Mora, M.L. Flores, H., Neaman, A. 2006. Métodos Recomendados Para Suelos Chilenos (Methods Recommended for Chilean Soils). Comisión Nacional de Normalización y Acreditación. Sociedad Chilena de la Ciencia del Suelo, Santiago, Chile, 164 p.

Scheible, W. R., Morcuende, R., Czechowski, T., Fritz, C., Osuna, D., Palacios-Rojas, N., Schindelasch, D., Thimm, O., Udvardiand, M.K., Stitt, M. 2004. Genome-wide reprogramming of primary and secondary metabolism, protein synthesis, cellular growth processes, and the regulatory infrastructure of Arabidopsis in response to nitrogen. Plant Physiol. 136(1), 2483-2499.

Schlegel, A.J., Nelson, D.W., Sommers, L.E. 1986. Field evaluation of urease inhibitors for corn production. Agron J. 78, 1007-1012.

Schuman, G.E., Stanley, A.M., Knudsen, D. 1973. Automated total nitrogen analysis of soil and plant samples Proc. Soil Sci. Soc. Am. 37, 480-481.

Selim, A.K., Mahmoud, S. 2015. Effect of sulfur and stabilized ammonium nutrition on nutrient uptake by wheat in clay and calcareous soils. Agricult Forest. 61(1), 121-125.

Tong, D., Xu, R. 2012. Effects of urea and $\left(\mathrm{NH}_{4}\right)_{2} \mathrm{SO}_{4}$ on nitrification and acidification of Ultisols from Southern China. J Environ Sci. 24(4): 682-689.

Wellburn, A.R. 1994. The spectral determination of chlorophylls a and $\mathrm{b}$, as well as total carotenoids, using various solvents with spectrophotometers of different resolution. J. Plant Physiol. 144(3), 307-313. 
Zerulla, W., Barth, T., Dressel, J., Erhardt, K., von Locquenghien, K.H., Pasda, G., Rädle, M., Wissemeier, A.H. 2001. 3,4-Dimethylpyrazole phosphate (DMPP) - a new nitrification inhibitor for agriculture and horticulture. An introduction. Biol. Fert. Soils. 34, 79-84.

Zheng-Qin, X., Tai-Qing, H., Yu-Chun, M.A., GuangXi, X., Zhao-Liang, Z. 2010. Nitrate and ammonium leaching in variable- and permanent-charge paddy soils. Pedosphere. 20(2), 209-216. 